\title{
RETROSPECTIVE STUDY OF UTERINE TUBES PATHOLOGICAL ABNORMALITIES IN SLAUGHTERED NON-PREGNANT COWS IN SULAIMANI PROVINCE.
}

\author{
MARDIN O. MOHAMMED and FARAIDOON A.S.M. AMIN \\ Department of Surgery and Theriogenology, College of Veterinary Medicine, Sulaimani University, Sulaimani, Kurdistan \\ Region - Iraq
}

Email: faraidoon.muhamad@univsul.edu.iq

Assiut University web-site: www.aun.edu.eg

ABSTRACT

Received at: 26/8/2015

Accepted: 25/10/2015
The current study was conducted to address the pathological conditions of uterine tubes of cows slaughtered at the abattoir in Sulaimani, Kurdistan Region-Iraq. The pathologic conditions were objected to macroscopic and microscopic examination of 404 samples of female genitalia collected from slaughtered non-pregnant cows. Collection of female genitalia samples was conducted from February to September 2014 by visiting the Qaragol slaughterhouse twice a week. The organs were observed macroscopically for pathological abnormalities and stained tissues with Haematoxyline and eosin. They were examined under microscope for determination of the type of lesion present in the organ. Among the 404 genitalia samples collected from the non-pregnant animals, $206(51 \%)$ were found without gross pathological abnormalities (with cyclic activity) and the 71(17.57) samples were found with gross pathological abnormalities of uterine tubes. Detected lesions in the uterine tubes included salpingitis $9.15 \%$, pyosalpinx $4.21 \%$, hemosalpinx $1.48 \%$, uterine tube adhesion $0.74 \%$, mesosalpinx cyst $0.74 \%$, nodules on mesosalpinx $0.74 \%$, occluded uterine tube $0.25 \%$, and presence of cysts on the uterine tube wall $0.25 \%$. Histopathologically, salpingitis was characterized by erosion of the mucosal layer lining, while pyosalpinx showed a heavy inflammatory cell reaction composed of a mixture of neutrophils and lymphocysts. Hemosalpinx showed the stromal hemorrhage in the core of the villus like folds of epithelium. Cystic uterine tube, (paratubal paramesonephric cyst), revealed a single layer of tubal type ciliated columnar epithelium resting on fibrous tissue of the normal fallopian tube. It was concluded that uterine tube abnormalities constitutes an percentage of $17.57 \%$ and salpingitis is the most common pathology of uterine tubes in non-pregnant cows.

Key words: Uterine tubes, abnormalities, non-pregnant cows, salpingitis, pyosalpinx.

\section{INTRODUCTION}

Farm animals are one of the fundamental pillars of the economy of Kurdistan region in general, and cows in particular as an economical unit from which people of Kurdistan get great benefit. Thus reproductive problems among cows have a direct influence on the nutritional needs of the people as well as on the economic status of the region (Amin, 2001). Infertility among farm animals is one of the great economic problems (Zerihun, 2001).

Abnormalities of uterine tubes of cows limit the transfer of male and female gametes may result in sterility or infertility. The gross abnormalities and lesions of the uterine tube like salpingitis, pyosalpinx, hydrosalpinx, occlusion, aplasia and other microlesion which are not palpable per rectum and could be responsible for reproduction failure in farm animals, and these tubular abnormalities may show repeat breeding of known or obscure etiology which requires to be confirmed by patency testing (Shivhare et al., 2012). According to the definition proposed by Zemjanis (1980), a repeat breeder cows refers to any cows that have failed to conceive after three or more services showing normal estrous cycles and no clinical pathologies. In repeat breeder cows, the cause of infertility might be either fertilization failure or early embryonic death Lamming \& Darwash, (1998); Bage, (2002) as well as Ferreira et al. (2008) working only with repeat breeder cows, observed that these animals show some degree of oviduct occlusion.

The percentage rate of uterine tube abnormalities in cows was recorded by Khasatiya et al. (1999) who recorded the fallopian tube patency testing as $16 \%$ in 
cow. Fathalla et al. (2000) mentioned that the oviductal lesions had 3.5\%. Kunbhar et al. (2003); Dorobantu, (2010); Shivhare et al. (2012) reported in their studies that the percentage of the disease was $60 \%, 9.27 \%, 25.2 \%$ respectively. In Iraq Amin, (2001); Ali, (2009) recorded the uterine tube abnormalities as $11.52 \%, 0.76 \%$.

The present study was conducted to determine the microscopic and macroscopic lesions of abnormalities of uterine tubes in non-pregnant cows slaughtered at the abattoir of Sulaimani province, Kurdistan regionIraq.

\section{MATERIALS and METHOD}

The study was conducted on 404 samples of nonpregnant cow's genitalia which were collected on two days of week from anew slaughterhouse in "Qaragol" district in Sulaimani province. The data collection was carried out from February to the end of September 2014. These samples were collected randomly from local breeds, the age of the animals was from 2- 5 years and no information regarding the identity and history of the animals were included in this study. The samples were transported in a cool box to laboratory of Veterinary Teaching Hospital at the College of Veterinary Medicine in the University of Sulaimani within three hours of the collection for gross pathological examination. The pregnant genitalia were excluded and all non-pregnant genitalia were examined visually for gross morphological or pathological abnormalities.

The uterine tubal patency assessment was carried out according to the method of Dawson, (1958) by injecting colored fluid (Indian ink) at their junction with the uterine horns of both right and left sides of tubes, free flow of stain from the other side (fimbriated end) was considered indicative of nonobstructed tubes. The uterine tube was classified and ranked (Ferreira et al., 2008) according to its patency (patent; partially patent; occluded). Uterine tubes were opened by midline incision and examined for inflammation, presence of pus and other changes were recorded and tissue samples were fixed in a plastic container which contains $10 \%$ buffered formalin for histopathological examination.

\section{RESULTS}

Non- pregnant genitalia from cows were examined; it was $206(51 \%)$ genitalia without gross pathological abnormalities (with cyclic activity) while 71(17.57) of them with gross pathological lesions of uterine tubes The different types of abnormalities of uterine tube in non-pregnant cows presented in Table (1).

Table 1: Gross-pathological abnormalities of uterine tube in cow's genitalia in the Sulaimani abattoir.

\begin{tabular}{|c|c|c|c|c|c|c|}
\hline $\begin{array}{l}\text { Pathological } \\
\text { Abnormalities }\end{array}$ & $\begin{array}{l}\text { R-side } \\
\text { No. }\end{array}$ & $\begin{array}{l}\text { L-side } \\
\text { No. }\end{array}$ & $\begin{array}{l}\text { Both side } \\
\text { No. }\end{array}$ & $\begin{array}{l}\text { Total } \\
\text { No. }\end{array}$ & $\begin{array}{c}\text { Percentage } \\
n=71\end{array}$ & $\begin{array}{c}\text { Percentage } \% \\
n=404\end{array}$ \\
\hline Pyosalpinx & 3 & 3 & 11 & 17 & 23.94 & 4.21 \\
\hline Salpingitis & 5 & 5 & 27 & 37 & 52.11 & 9.15 \\
\hline Occluded uterine tube & 1 & & & 1 & 1.40 & 0.25 \\
\hline Uterine tube adhesion & 2 & 1 & & 3 & 4.22 & 0.74 \\
\hline Hemosalpinx & 2 & & 4 & 6 & 8.45 & 1.48 \\
\hline Mesosalpinx cyst & 2 & 1 & & 3 & 4.22 & 0.74 \\
\hline $\begin{array}{l}\text { Nodules on } \\
\text { mesosalpinx }\end{array}$ & 2 & 1 & & 3 & 4.22 & 0.74 \\
\hline $\begin{array}{l}\text { Cyst on uterine tube } \\
\text { wall }\end{array}$ & 1 & & & 1 & 1.40 & 0.25 \\
\hline Total & 18 & 11 & 42 & 71 & 100 & $\mathbf{1 7 . 5 7}$ \\
\hline
\end{tabular}




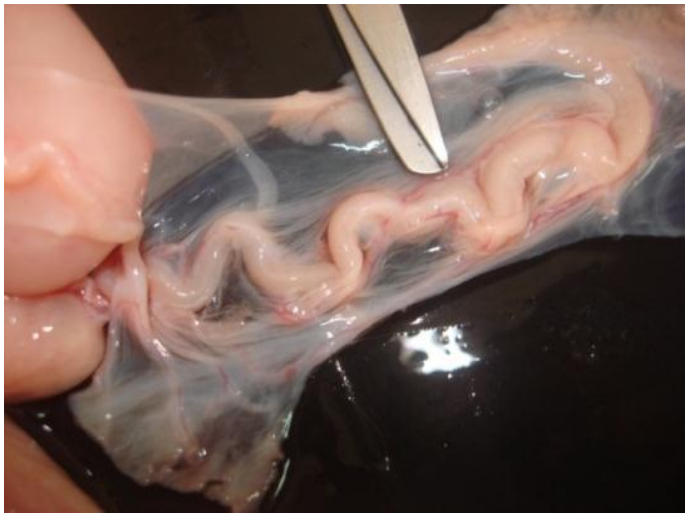

Fig. 1: Pyosalpinx of uterine tube, thicken wall accumulated pus in the luminal tube.

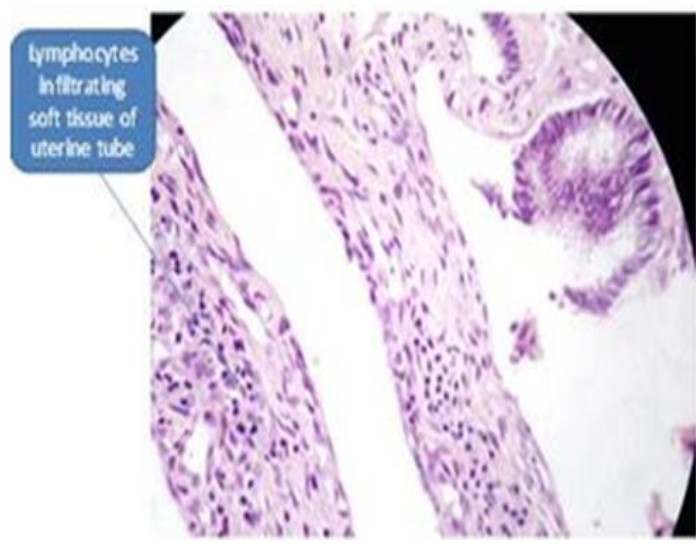

Fig. 3: Chronic salpingitis, it shows infiltration of mononuclear inflammatorycells mainly lymphocytes fibrous tissue which lack epitheliallining (H\&E stain 100X).

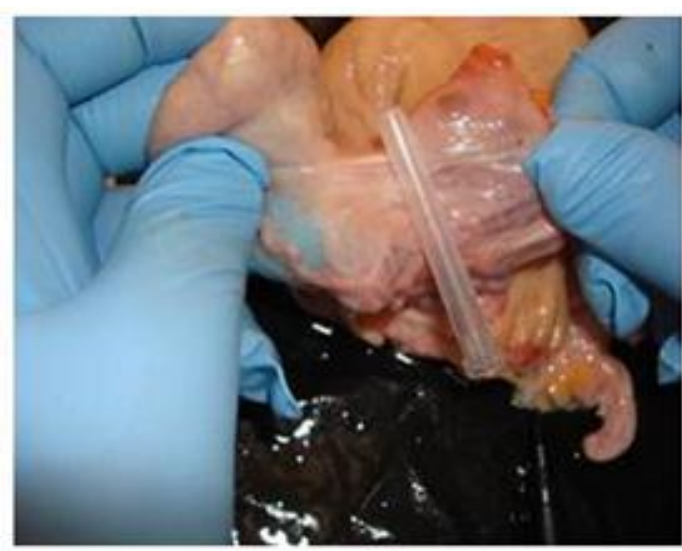

Fig. 5: Uterine tube adhesion, adhesion between Mesosalpinx and perisalpingial tissues.

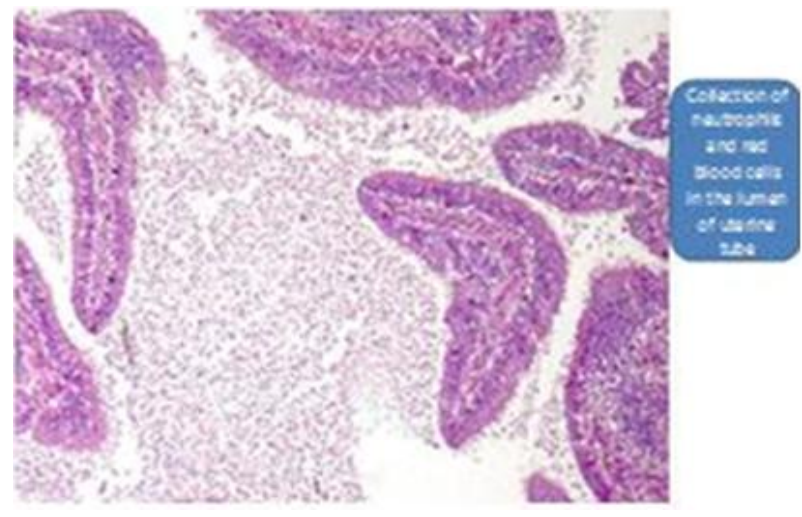

Fig. 2: Pyosalpinx shows a heavy Inflammatory cell reaction composed of a mixture of neutrophils and lymphocytes (H\&E stain 400X).

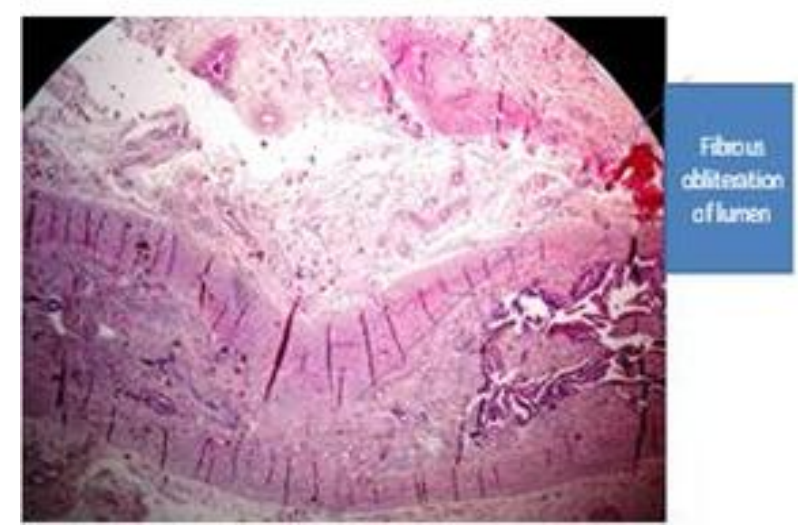

Fig. 4: Occlusion of the uterine tube longitudinal section shows, obliteration of lumen by

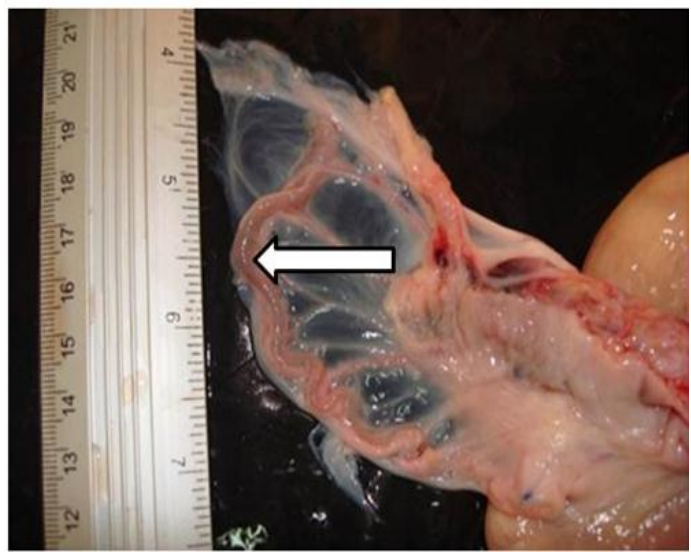

Fig. 6: Hemosalpinx; swelling of uterine tube filled with bloody discharge. 


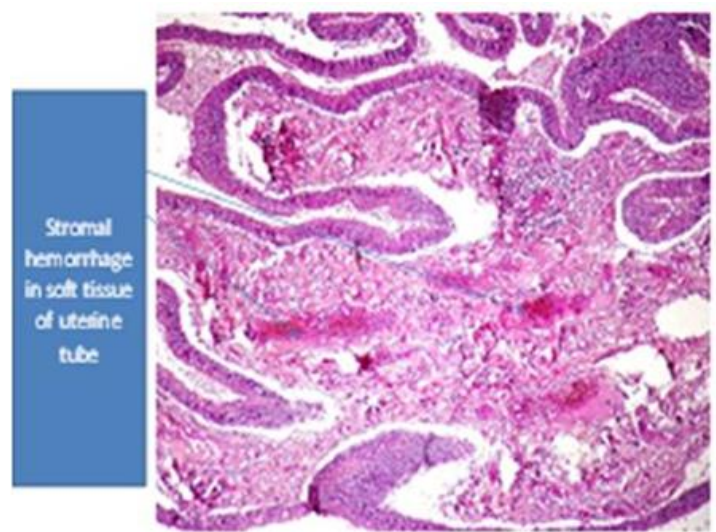

Fig. 7: Shows the uterine tube with stromal Hemorrhage in the core of the villus like folds of epithelium (H\&E stain 100X).

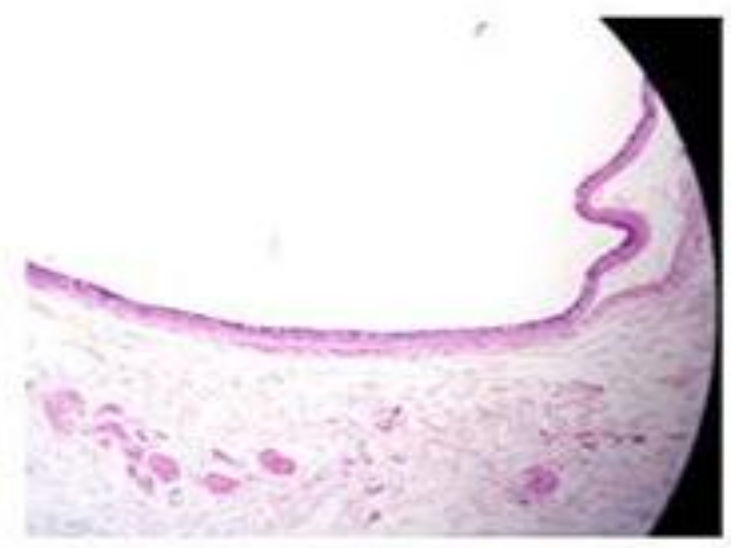

Fig. 9: Mesosalpinx cyst; describes the cyst, which is called paramesonephric cyst and is a remnant of paramesonephric (Mullerian) duct system (H\&E stain 100X).

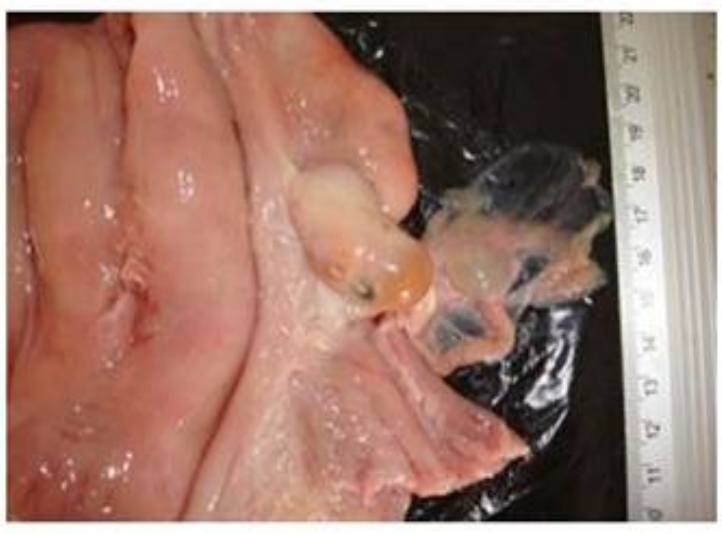

Fig. 11: Showing the cyst onuterine tube wall in the right side.

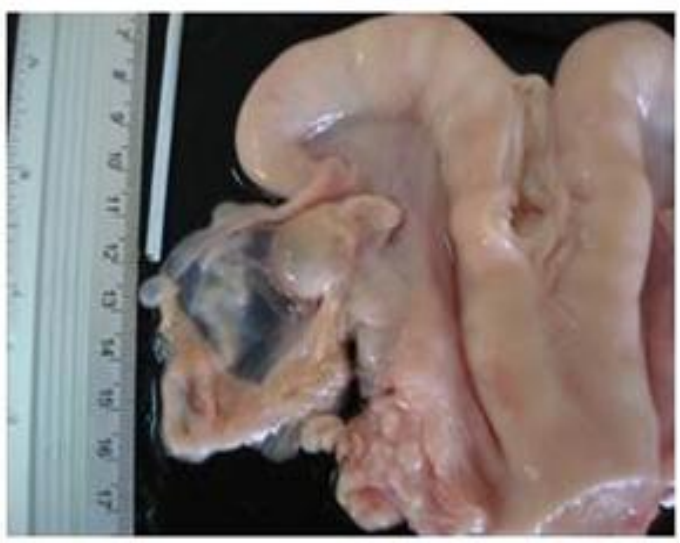

Fig. 8: Mesosalpinx cyst, whichis $0.5-0.7 \mathrm{~cm}$ in diameter.

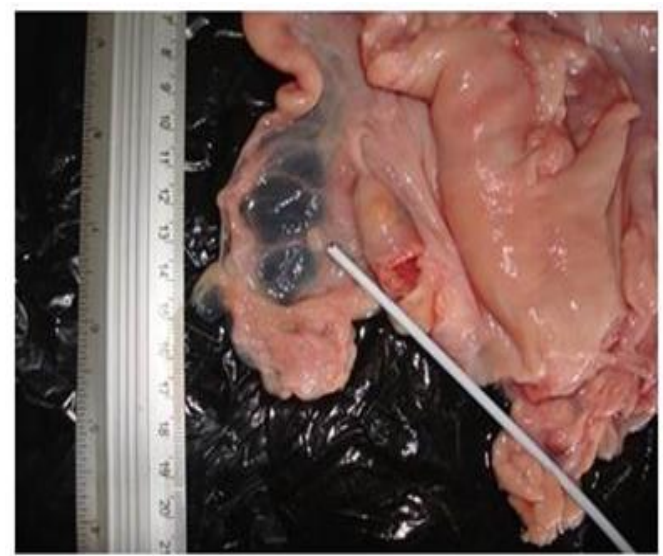

Fig. 10: Nodule on mesosalpimx in the left part of genital tract.

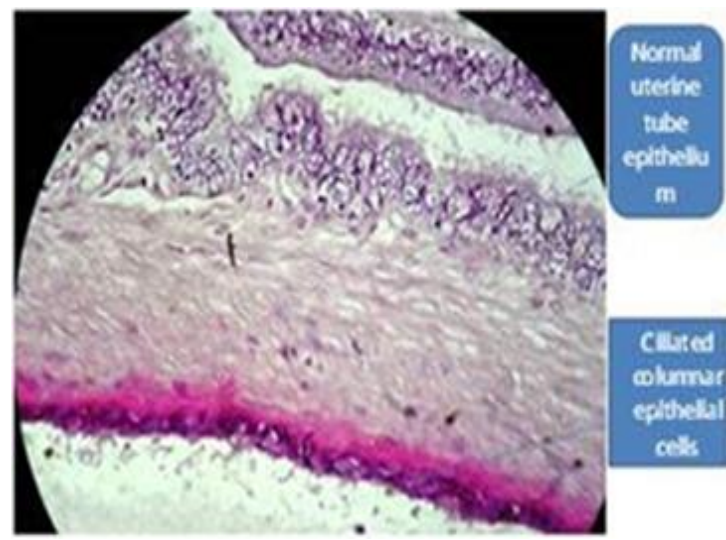

Fig. 12: Cystic on uterine tube, paratubal paramesonephric cyst, also called (Hydatic of Morgani), single layer of tubal type Ciliated columnar epithelium resting on fibrous Tissue of the normal fallopian tube (H\&Estain 400X). 


\section{DISCUSSION}

The present abattoir study has provided useful information on the types and prevalence of gross pathological abnormalities of uterine tubes of cows in Sulaimani region. About 71 genitalia (17.57\%) showed one or more abnormalities as in Table (1).

The total percentage of uterine tubal abnormalities $17.57 \%$ as in Table (1) from the total reproductive tracts is higher than the results of other studies by Amin (2001); Ali (2009); and Dorobantu (2010) which were $11.52 \%, 0.76 \%$, and $9.27 \%$ respectively, and lower than the observation mentioned by Shivhare et al. (2012) which was $25.2 \%$.

The percentage of the pyosalpinx reaches $4.21 \%$ from the total reproductive tracts as in Fig. (1), and the result is lower than the rate of Kunbhar et al. (2003) which was $26.2 \%$ and higher than the rates of Shivhare et al. (2012) which were $0.8 \%$. Pyosalpinx occurs following ascending uterine infections and this agree with the suggestion of Kennedy and Miller (1993).Microscopic appearance of pyosalpinx in present study is in agreement with McEntee (1990) that a heavy inflammatory cell reaction is composed of a mix of neutrophils and lymphocytes associated with a notable degree of tissue edema as in Fig. (2).

Salpingitis have an percentage of $9.15 \%$, which were observed more bilaterally than unilaterally, grossly consisted of edematous appearance and thickening of oviduct. The percentage rate of salpingitis in cows, in present study was higher than $0.68 \%, 0.54 \%, 3 \%$, $1.1 \%$ and $3.2 \%$ as reported by Herenda (1987), Chaudhari and Paul-Bokko (2000), Fathalla et al. (2000), Simmenew et al. (2011) and Shivhare et al. (2012) respectively, and lower than $23 \%$ as reported by Kunbhar et al., (2003). In Iraq, the observation of salpingitis was lower than the recorded by Amin, (2001) which was $10.54 \%$ and higher than the rate diagnosed by Azawi et al. (2008) which was $1.2 \%$. In this study, along with salpingitis adhesions, mesosalpingitis with adhesions were also found; the obtained result agreement with Ali (1989) that referred the salpingitis was associated with ovaroburasl adhesion, and the obtained result was agree with Ali (1989) that the salpingitis is very frequently associated with pathological conditions in the ovary, the most common lesion is that of retained and cystic corpus luteum. Histopathologic examination, chronic salpingitis which is in agreement with Hatipoglu et al. (2002) showed erosion of lining mucosal layer caused by inflammation and explained the chronic salpingitis, and there is denudation of mucosa resulting from inflammatory cell infiltrate of lamina propria composed of chronic inflammatory cells in form of lymphocytes as in Fig. (3).
Occludedd uterine tube revealed $0.25 \%$ as in Fig. (4). The percentage being lower than the percentage recorded by several authors (Kessy and Noakes, 1985; Chaudhari and Paul- Bokko, 2000; Shivhare et al., 2012) were $12.4 \%, 1 . \%, 15.2 \%$ respectively. In Iraq, the rate of percentage in this study is lower than the rate recorded by Ali, (1989) which was $8.61 \%$ and the rate reported by Alwan, (1990) which was (4.2\%) and Azawi et al. (2008) observed 1.5\%. Uterine tube adhesion revealed $0.74 \%$ as in Fig. (5) which represented by adhesion between mesosalpinx and perisalpingial tissues.

The percentage of hemosalpinx in this study recorded $1.48 \%$ as in Fig. (6). It is higher than the percentage of Herenda (1987) which was $0.06 \%$ while it is lower than the percentage reported by Fathalla et al. (2000) which was $(2 \%)$. Hemosalpinx is characterized by thickening the wall of uterine tube due to filling with bloody discharge, which is in agreement with Azawi et al. (2008). In Iraq the percentage of present study is higher than the percentage of (Ali, 1989; Azawi et al., 2008). The histopathologically section, is in agreement with Azawi et al. (2008) which showed the uterine tube with stromal hemorrhage in the core of the villus like folds of epithelium as in Fig. (7).

Mesosalpinx cyst showed an percentage $0.74 \%$ as in Fig. (8). The cysts found on mesosalpinx were (0.5$0.7) \mathrm{cm}$ in diameter. Microscopically, present study describes a cyst called paramesonephric cyst which is a remnant of paramesonephric (Mullerian) duct system as in Fig. (9). Schlarfer and Miller, (2007) state that these cysts do not appear to have any effect on fertility but cyst formation may be associated with hormonal dysfunction, and Tsumura et al. (1982) reported that cyst formation in the uterine tube was most frequently seen in the fimbriae in cows and in the mesosalpinx in sows, and they also describe that the sex hormones and oviductal constrictions might cause oviduct cysts.

Nodules on mesosalpinx revealed $0.74 \%$ as in Fig. (10). McEntee, (1990) described that nodules are found occasionally in the mesosalpinx of queen, bitch, cow, and mare, relatively few of the nodules are large enough to be recognized readily on gross examination.

Cyst on uterine tube wall reveals $0.25 \%$ of cyst related to the wall of uterine tube as in Fig. (11). The percentage of present study is similar of the percentage observed by Kessy and Noakes (1985) which is $0.25 \%$ and is lower than the value of $16.5 \%$, and $4.6 \%$ which is reported by Tsumura et al. (1982) and Kunbhar et al. (2003) respectively. The result agrees with McEcntee (1990), who states that these cysts are so close to or adjacent to the uterine tube. Kessy and Noakes (1985) that a single mucosal cyst which caused partial occlusion of the tube. 
Microscopic examination, that was paratubal paramesonephric cyst also called Hydatid of Morgangni, showed single layer of tubal type ciliated columnar epithelium resting on fibrous tissue of the normal uterine tube as in Fig. (12), this is agreement with McEntee, (1990).

\section{REFERENCES}

Ali, A.A.A. (1989): Macroscopical Study of Oviduct in Local Breed Cows. High Diploma Thesis, college of Vet. Medicine, Mosul University, Iraq.

Ali, T.G. (2009): In Vitro and In vivo Study of Infertility of Cows in Sulaimani Region. PhD Thesis, Dept Surgery\& Theriogenology, College Veterinary Medicine, University of Sulaimani.

Alwan, A.F.; Ali, J.B. and AL-Dahash, S.Y.A. (1990): A macroscopical study of female genital system of local Iraqi cows. Iraqi Journal Veterinary Science, 3(1): 1-11.

Amin, F.A.S.M. (2001): Clinical and Abattoir Study of Reproductive Problems in Local Breed Cows in Sulaimani District. M. V. Sc. Thesis College of Vet. Medicine, Sulaimani University.

Azawi, O.I.; Ali, A. and Lazim, E.H. (2008): Pathological and a anatomical abnormalities affecting buffalo cows reproductive tracts in Mosul. Iraqi Journal of Veterinary Science, 22(2): 59-67.

Bage, R. (2002): Repeat breeding in dairy heifers: follicular dynamics and estrous cycle characteristics in relation to sexual hormone patterns, Theriogenology, 57 (9): 2257-2269.

Chaudhari, S.U.R. and Paul-Bokko. (2000): Reproductive status, pregnancy wastage and incidence of gross genital abnormalities in Cows slaughtered at Maiduguri Abattoir, Nigeria, Pakistan Veterinary Journal, 20 (4).

Dawson, F.L.M. (1958): Studies on the tubal patency of the cow. Japanese Journal of Veterinary Research, 70(487).

Dorobantu, I. (2010): Research on Cows Infertility Oviduct and Cervix due to disease. $\mathrm{PhD}$ Thesis, Domian Vet. Medicine, University of Agronomical Science \& Veterinary Medicine, Iasi.

Fathalla, M.; Hailat, N.; Lafi, S.Q.; Abu Basha, E. and Al-Sahil, A. (2000): An Abattoir Survey of Gross Reproductive Abnormalities in the Bovine in Northern Jordan. Israel Veterinary Medical Association, 55(3): 1-7.

Ferreira, R.; Oliveira, J.F.; Antoniazzi, A.Q.; Moraes, J.C.F.; Henkes, L.E.; Bordignon, V. and Goncalves, P.B. (2008): Relationship between clinical and postmortem evaluation in repeat breeder beef cows. Santa Maria Ciecncia Rural, 38(4).
Herenda, D. (1987): An Abattoir Survey of reproductive organ abnormalities in beef heifers. The Canadian Veterinary Journal, 28: 33-37.

Kessy, B.M. and Noakes, D.E. (1985): Uterine Tube Abnormalities as a Cause of Bovine Infertility. Veterinary Record, 117: 122-123.

Kennedy, P.C. and Miller R.B. (1993): The female Genital System. In: Jubb K. V. F., Kennedy P. C. and Palmer N. $4^{\text {th }}$ Ed. Pathology of Domestic Animals Vol. 3. Academic Press (San Diego), 349-454.

Khasatiya, C.T.; Kavani, F.S.; Dhami, A.J.; Panchal, M.T. and Shah, R.G. (1999): Fallopian Tube Patency Testing and Therapeutic Measures in Repeat Breeding Bovines. Bioscience in Animal Production and Thai Buffalo Association, 1: 69-79.

Kunbhar, H.K.; Samo, M.U.; Rind, R.; Kaka, I. and Channa, A.D. (2003): Gross Pathological Studies on Female Reproductive Organs Thari Cow (Bos indicus). Journal of Animal and Veterinary Advances, 2(2): 58-63.

Lamming, G.E. and Darwash, A.O. (1998): The use of milk progesterone profiles to characterize components of sub fertility in milked dairy cows. Animal Reproduction Science, 52 (3): 175-190.

McEntee, K. (1990): Reproductive Pathology of Domestic Animals. $1^{\text {st }}$ Ed., Academic press, SanDiego, 167-168.

Shivhare, M.; Dhurvey, M.; Gupta, V.K.; Nema, S.P.; Mehta, H.K.; Jain Reshma; Singh and Shakaya Vinod. (2012): Infertility du to fallopian tube affections. DHR International Journal Biomedical Life Science, 3(1): 2278-8301.

Simenew, K.; Bekana, M.; Fikre, L.; Tilahum, Z. and Wondu, M. (2011): Major Gross Reproductive Tract Abnormalities In Female Cattle Slaughtred At Sululta Slaughterhouse In Ethiopia. Global Veterinarian, 6(6): 506-513.

Tanabe, T.Y. and Almquist, J.O. (1967): The nature of sub fertility in dairy heifers. Gross genital abnormalities. Agricultural Experiment Station, 736.

Tsumura, I.; Sasaki, H.; Minami, S.; Nonami, K. and Nakaniwa, S. (1982): Cyst formation in mesosalpinx, mesoovarium and fimbria in cows and sows. Japan journal veterinary science, 44: 1-8.

Zemjanis, R. (1980): Repeat -breeding or conception failure in cattle. In. Morrow, D.A. Current therapy in Theriogenology. Philadelphia: Saunders, Cap., 5: 205-213.

Zerihun, Y. (2001): A gross morphological study of genital organs from female Zebu cattle at Raya valley, north Ethiopia. DVM thesis, faculty of veterinary medicine, AAU, Debre zeit, Ethiopia. 


\section{دراسة مرضية لقناة البيض في الأبقار غير الحوامل المذبوحة في محافظة السليمانية \\ ماردين عمر محمد ، فريلون عبل الستار محمد أمين}

Email: faraidoon.muhamad@univsul.edu.iq

Assiut University web-site: www.aun.edu.eg

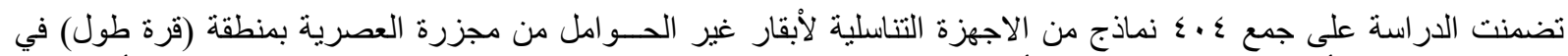

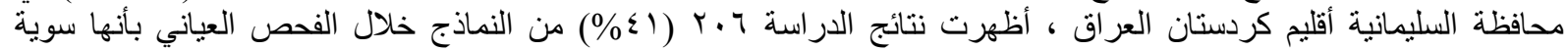

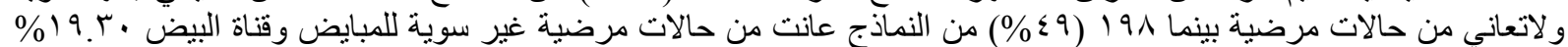

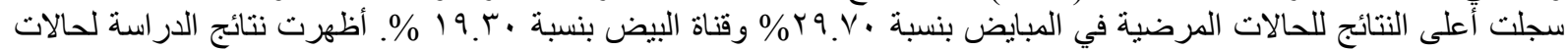

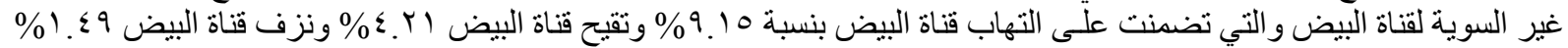

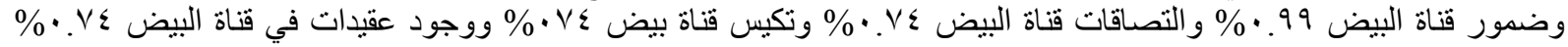

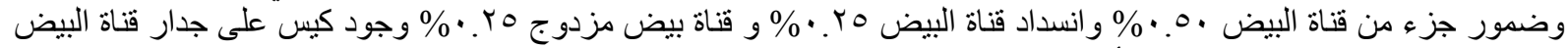

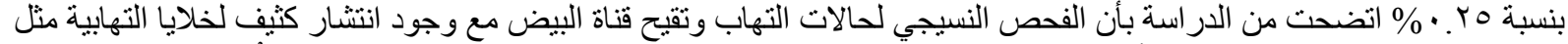
غلايا اللمفية و neutrophil وقد أستتنج من الدراسة وجود حالات مرضية غير سوية لقناة البيض في الأبقار الدذبوحة بنسبة 